УДК 582.682.2:581.43

DOI https://doi.org/10.11603/2312-0967.2021.3.12439

\title{
АНАТОМІЧНА БУДОВА ПІДЗЕМНИХ ОРГАНІВ КАТРАНУ КОКТЕБЕЛЬСЬКОГО (CRAMBE KOKTEBELICA (JUNGE) N. BUSCH)
}

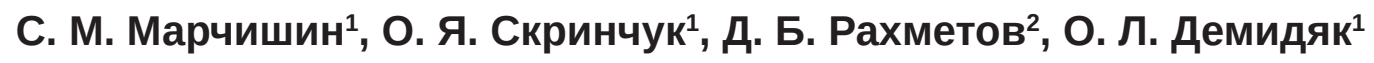 \\ Тернопільський національний медичний університет імені І. Я. Горбачевського МОз \\ України ${ }^{1}$ \\ Національний ботанічний сад імені М. М. Гришка НАН України² \\ svitlanafarm@ukr.net
}

ІНФОРМАЦІЯ

Надійшла до редакції / Received: 22.03.2021

Після доопрацювання / Revised: 15.09.2021

Прийнято до друку / Accepted: 17.09.2021

\section{Ключові слова:}

катран коктебельський; анатомічна будова;

корінь;

стеблекорінь.

\section{АНОТАЦІЯ}

Мета роботи: визначення мікроскопічних діагностичних ознак підземних органів катрану коктебельського (C. koktebelica (Junge) N. Busch).

Матеріали і методи. Мікропрепарати кореня готували зі свіжозібраної, фріксованої в суміші етанол-гліцерин-вода очищена (1:1:1) та висушеної, а потім розмоченої сировини. Анатомічну будову вивчали на препаратах із поверхні та поперечних зрізах, які робили за загальноприйнятою методикою. Використовували світловий мікроскоп «БІОЛАМ ЛОМО» (Росія) при збільшенні у 80, 120, 160, 400, 600 та 800 разів. Отримані дані фріксували цифрровою фротокамерою OLYMPUS SH - 21. Фотограсрії обробляли за допомогою комп'ютерної програми «Adobe Photoshop CS3».

Результати й обговорення. Анатомічна будова кореня. Корінь на поперечному зрізі округлої форми. Перидерма представлена 2-4 шарами паренхімних клітин. Добре розвинута корова паренхіма, яка утворена паренхімними тонкостінними клітинами. У коренях другого і наступних років серед клітин корової паренхіми зустрічаються невеликі скупчення склереїд, які відсутні в коренях першого року. Тип будови центрального циліндра безпучковий. Камбій добре помітний. Запасною речовиною кореня катрану коктебельського є крохмаль, а в оболонках судин первинної та вторинної ксилеми - білок.

Анатомічна будова видозміни кореня (стеблекорінь, каудекс). Осьовий орган на поперечному зрізі округлої форми. Покривна тканина багатошарова епідерма, клітини якої паренхімні, товстостінні. Опушення рідке, представлене простими одноклітинними волосками. Добре розвинена корова паренхіма, яка складається 3 паренхімних тонкостінних клітин. У коровій частині зустрічаються луб'яні волокна. Центральний осьовий циліндр безпучкової будови, камбій добре виражений. Домінуюча тканина ксилеми лібриформ. Серцевина виражена, виповнена.

Клітини корової паренхіми та серцевини накопичують крохмаль у вигляді простих крохмальних зерен, оболонки клітин судин та деяких клітин серцевини - білок.

Висновки. Досліджено анатомічну будову підземних органів катрану коктебельського (коренів і стеблекореня) та виявлено основні мікроскопічні діагностичні ознаки, які будуть використані для розробки методів контролю якості на нову лікарську рослинну сировину.

ISSN 2312-0967. Фармацевтичний часопис. 2021. № 3 
Фармацевтична ботаніка

Pharmaceutical botany

Діагностичними ознаками кореня є:

- скупчення склереїд у коровій паренхімі кореня другого, третього та наступних років;

- прості крохмальні зерна з тріщинкою або з вираженими денними і нічними шарами;

- $\quad$ білок у клітинах ксилеми.

Діагностичними ознаками стеблекореня є:

- $\quad$ покривна тканина - багатошарова епідерма;

- $\quad$ рідке опушення простими одноклітинними волосками;

- наявність луб'яних волокон у коровій паренхімі;

- домінування у ксилемі механічної тканини.

Вступ. Рід Катран (Crambe L.) родини капустяні (Brassicaceae) представлений однорічними і багаторічними рослинами, які мають широкий ареал поширення у світі - зростають у Європі, на сході Аорики та на південному сході Азії $[1,2]$. Деякі види можуть зустрічатися в передгір'ях Криму і на Керчинському півострові [3]. Рід налічує 44 види. У орлорі України наявні 8 видів роду Катран $[4,5]$.

Види роду Катран мають різноманітне застосуванн ня: як овочеві або кормові рослини, як олійні культури, як джерело біопалива (насіння має до $60 \%$ ерукової кислоти). Застосовують рослини також у харчовій промисловості для виготовлення кондитерських виробів, у лакофарбовій та хімічній промисловості [6].

До категорії вразливих та зникаючих видів, що занесені до Червоної книги України [7-9], належить представник роду Катран катран коктебельський (C. koktebelica (Junge) N. Busch), який зростає в Гіре ському Криму - Карадагському природному заповіднику і в Коктебельській долині (на території масиву Карадаг та поблизу с. Коктебель) [10]. Однак останні дослідження спростовують ендемічність даного виду [11]. Крім того, C. koktebelica занесений в додаток до Бернської конвенції [12].

Катран коктебельський (C. koktebelica (Junge) N. Busch) - це літньо-зимовозелений гемікриптосріт, рослина, в якої під час посухи або низьких температур, тобто за несприятливих умов, бруньки відновлення знаходяться у поверхневому шарі ґрунту i, таким чином, захищені підстилкою з рослин та снігу (рис. 1).

Це напіврозетковий, конодієвий багаторічний моі нокарпик заввишки від 1,5 до 2,5 м; 3 прямостоячим, майже від основи галузистим стеблом, опушеним густими, простими волосками, спрямованими вниз. Листки, зібрані у розетку, дуже великі, завдовжки до 30 см. Розеткові листки 3 опушенням. Волоски прості з довгими, відігнутими назад від ліроподібних, ліроподібно-пірчастих до майже цілісних (зрідка), по краю 3 нерівномірно різновеликозубчастими, широкотрикутними зубчиками. Суцвіття - складна розлога китиця, що складається з білих, дрібних квіток. Плоди - гладенькі нерозкривні двочленні стручечки 3 майже кулястими верхніми члениками, з діаметром від 4 до 4,5 мм. Цвіте катран коктебельський у квітнітравні; плодоносить - у червні-вересні. Розмножень ня відбувається насінням. У фразу цвітіння рослини переходять на 3-5-й рік [13].

Катран коктебельський зростає на сухих глинистих схилах із змитими ґрунтами на приморських обривах і вапняково-щебенистих схилах. Рослини можуть рости поодиноко або невеликими групами [4].

У джерелах наукової літератури відсутня інорормація про анатомічне дослідження катрану коктебельського, тому метою наших досліджень було провести мікроскопічний аналіз підземних органів даного виду, запропонованого відділом нових культур НБС НАН України імені М. М. Гришка, де на базі Національного ботанічного саду триває робота із введення рослин роду Катран у культуру.

Матеріали і методи. Мікропрепарати для вивчення анатомічної будови кореня готували зі свіжозібраної, фріксованої в суміші етанол-гліцерин-вода очищена (1:1:1) та висушеної, а потім розмоченої сировини. Анатомічну будову вивчали на препаратах із поверхні та поперечних зрізах, які робили за загальноприйнятою методикою $[14,15]$. Для роботи використову-

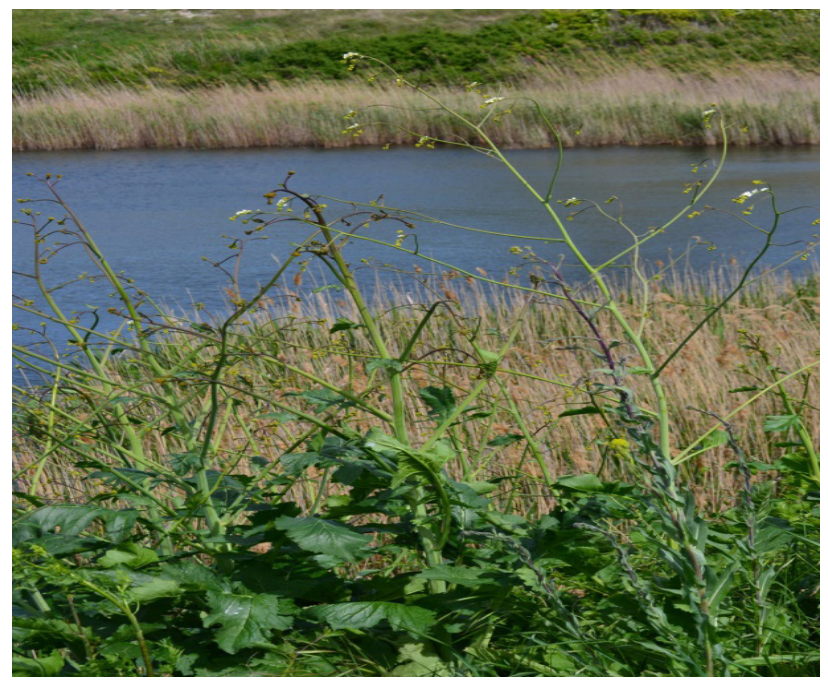

Рис. 1. Катран коктебельський

(C. koktebelica (Junge) N. Busch).

ISSN 2312-0967. Pharmaceutical review. 2021. № 3 
Фармацевтична ботаніка

\section{Pharmaceutical botany}

вали світловий мікроскоп «БІОЛАМ ЛОМО» (Росія) при збільшенні у 80, 120, 160, 400, 600 та 800 разів. Отримані дані фріксували цифровою фотокамерою OLYMPUS SH - 21. Фотографії обробляли за допомогою комп'ютерної програми «Adobe Photoshop CS3».

\section{Результати й обговорення.}

\section{Анатомічна будова кореня}

Корінь катрану коктебельського на поперечному зрізі округлої фрорми (рис. 2). Покривна тканина перидерма, яка представлена 2-4 шарами паренхімних клітин (рис. 3). Корова паренхіма утвон рена паренхімними тонкостінними клітинами, добре розвинена (рис. 4).

У коренях другого, третього і наступних років серед клітин корової паренхіми зустрічаються невеликі скупчення механічних клітин - склереїд (рис. 5, А), які забарвлюються аніліну сульфратом у жовтий колір (рис. 5, Б). У коренях першого року склереїди відсутні.

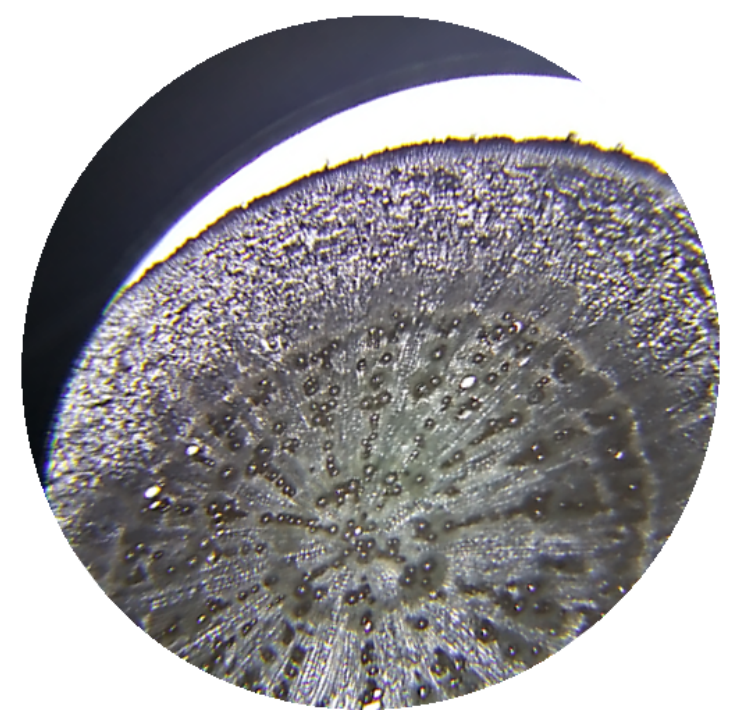

Рис. 2. Фрагмент кореня катрану коктебельського на поперечному зрізі.

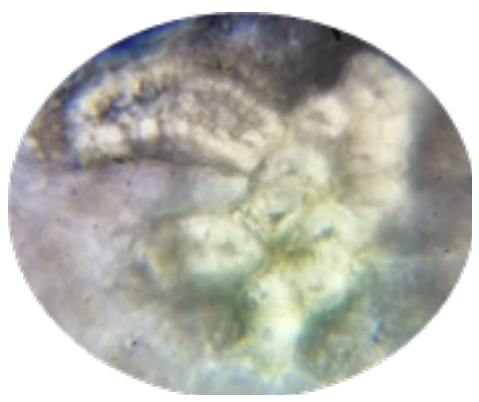

A

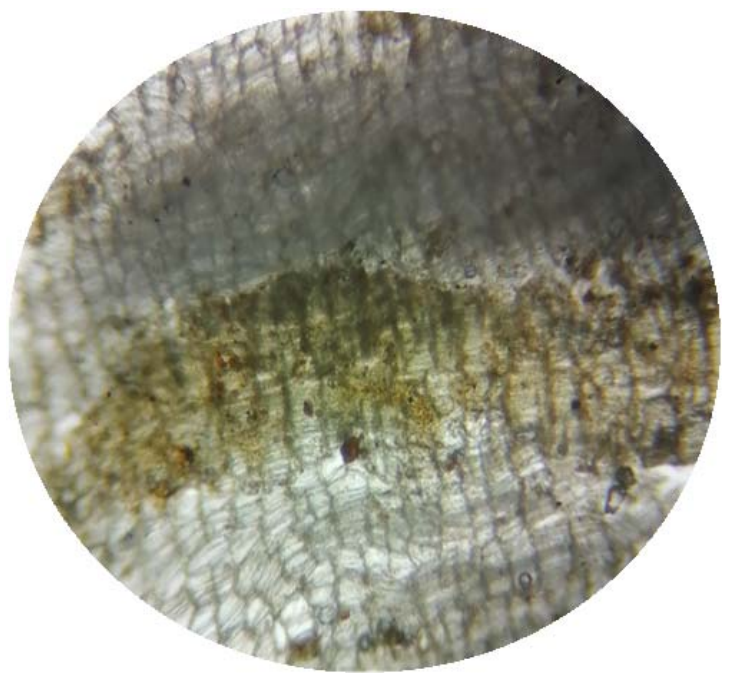

Рис. 3. Фрагмент перидерми кореня катрану коктебельського.

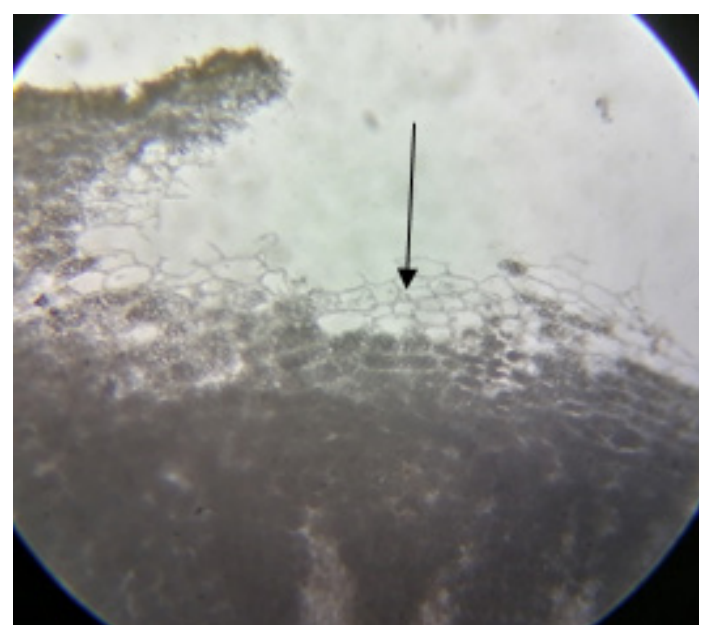

Рис. 4. Фрагмент корової паренхіми кореня катрану коктебельського, клітини якої заповненні запасаючою речовиною.

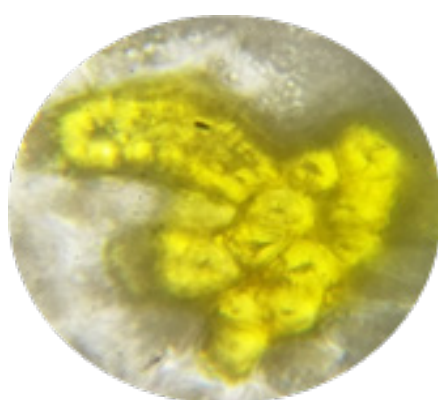

Б

Рис. 5. Склереїди кореня другого року катрану коктебельського: А - до обробки аніліну сульфратом, Б - після обробки реактивом.

ISSN 2312-0967. Фармацевтичний часопис. 2021. № 3 
Тип будови центрального циліндра безпучковий. Камбій добре помітний. Ксилема представлена, в основному, деревинною паренхімою, лібрисрормом та драбинчастими судинами (рис. 6). У коренях другого року неозброєним оком помітні річні кільця ксилеми. В центрі знаходяться залишки первинної ксилеми.

Запасаючою речовиною кореня картану коктебельського є крохмаль, який накопичується в клітинах корової паренхіми та деревини (рис. 4, 7). Крохмальні зерна прості, у деяких наявна в центрі тріщинка, в інших - виражені денні та нічні шари (рис. 8). Під дією розчину Люголя крохмальні зерна набувають темно-сріолетового забарвлення (рис. 7), а оболонки судин первинної та вторинної ксилеми забарвлюються в жовтий колір, що свідчить про наявність білка (рис. 7).

Анатомічна будова видозміни кореня (стеблекорінь, каудекс)

Осьовий орган на поперечному зрізі округлої фрорми (рис. 9). Покривна тканина - багатошарова епідерма (рис. 10, 11). Клітини епідерми паренхімні, товстостінні. Опушення рідке та представлене простими одноклітинними волосками (рис. 12).

Корова паренхіма добре розвинена та представлена паренхімними тонкостінними клітинами. В коровій частині зустрічаються скупчення клітин механічної тканини - луб'яних волокон, які під дією розчину Люголя забарвлюються в жовтий колір (рис. 13).

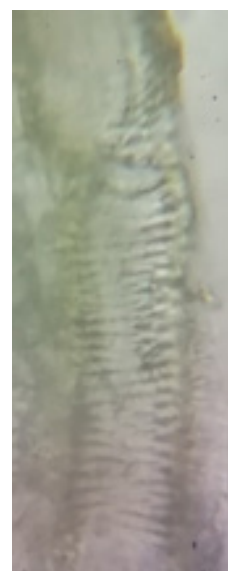

Рис. 6. Фрагмент драбинчастої судини кореня катрану коктебельського на поздовжньому зрізі.

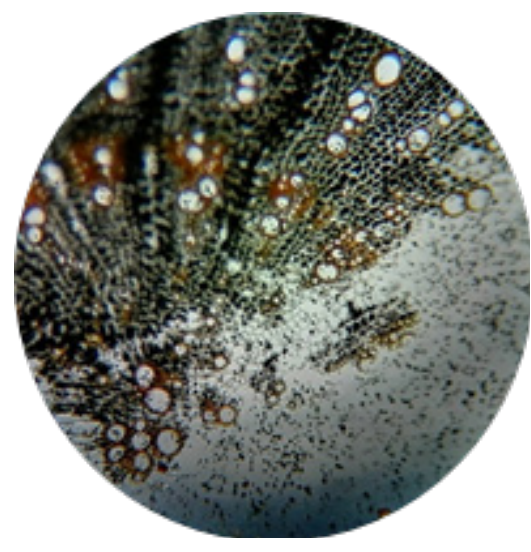

Рис. 7. Фрагмент поперечного зрізу кореня катрану коктебельського, клітини деревини якого набули темно-сріолетового кольору (крохмальні зерна), а оболонки первинної і вторинної ксилеми - жовтого (білок).

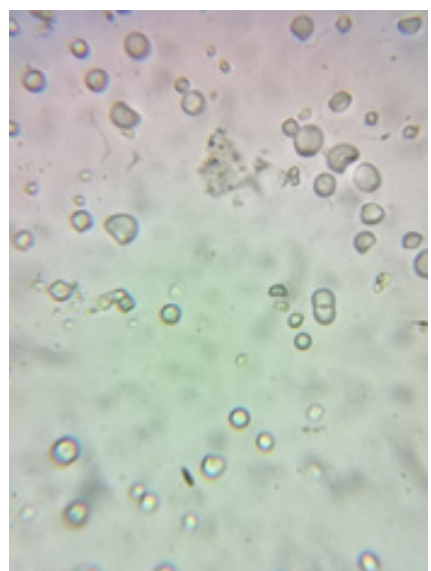

Рис. 8. Крохмальні зерна кореня катрану коктебельського.

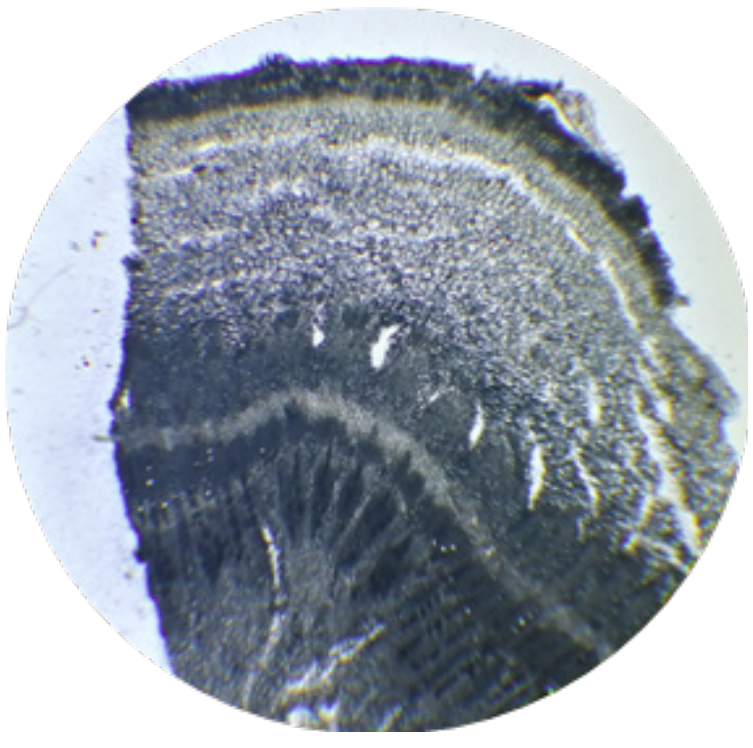

Рис. 9. Фрагмент поперечного зрізу стеблекореня катрану коктебельського.

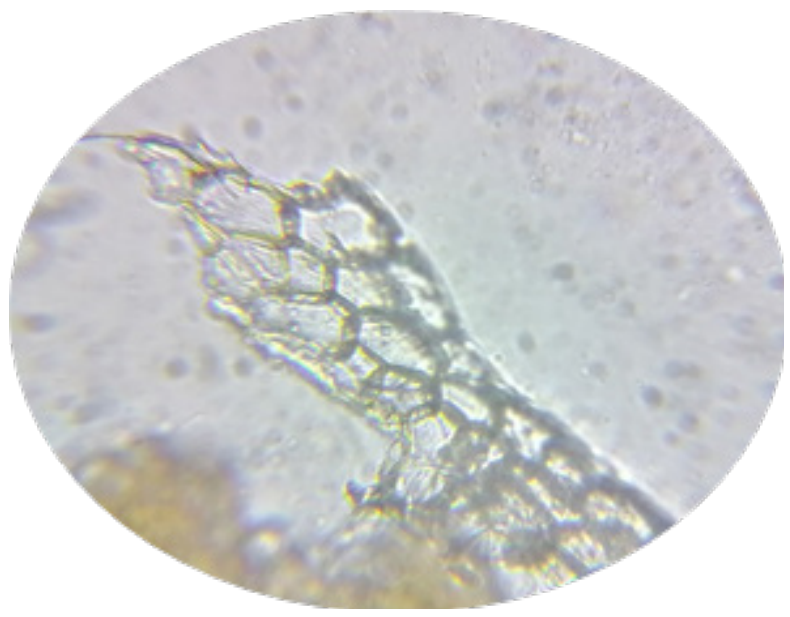

Рис. 10. Фрагмент епідерми стеблекореня.

ISSN 2312-0967. Pharmaceutical review. 2021. № 3 
Фармацевтична ботаніка

Pharmaceutical botany

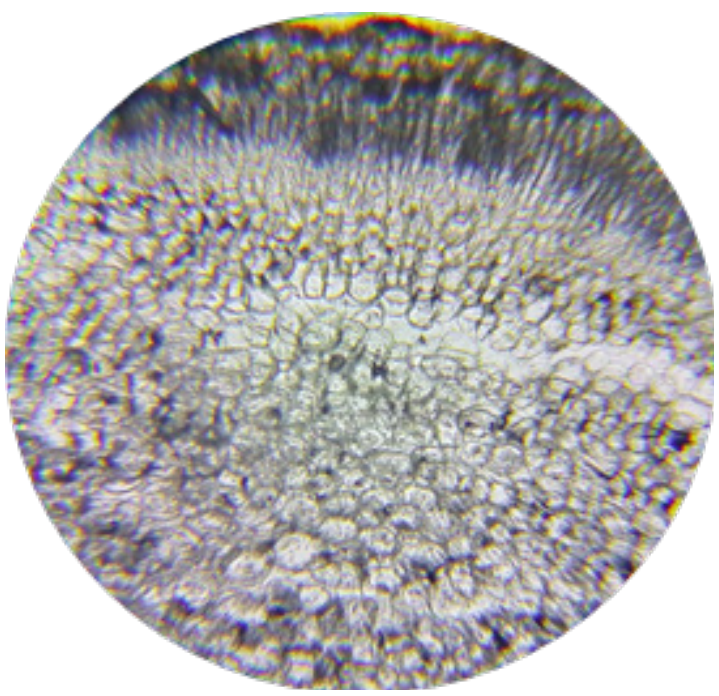

Рис. 11. Фрагмент покривної тканини та корової паренхіми стеблекореня.

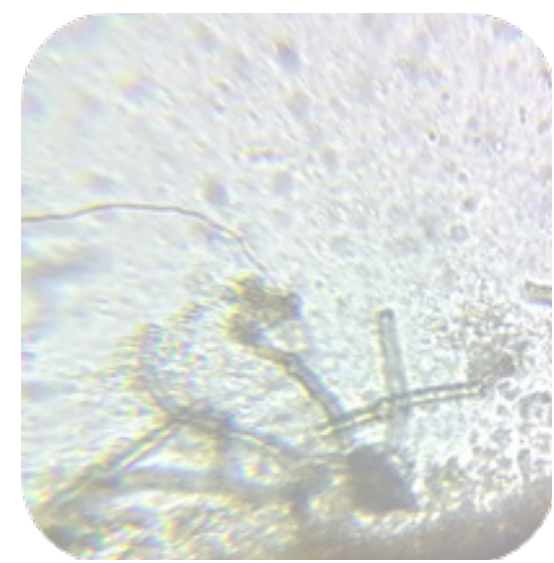

Рис. 12. Фрагмент опушення епідерми стеблекореня.

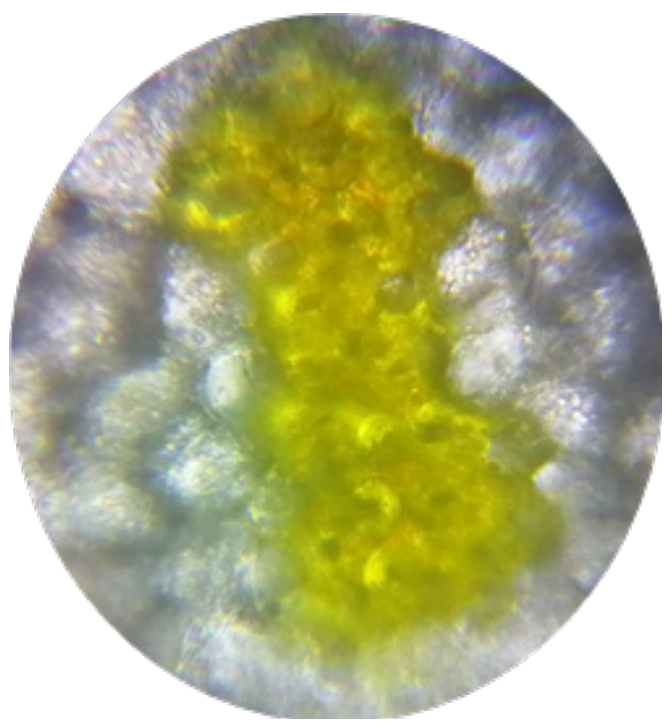

Рис. 13. Фрагмент луб'яних волокон осьового органу катрану коктебельського.
Центральний осьовий циліндр безпучкової будови, камбій добре виражений. Домінуюча тканина ксилеми - механічна - лібриформ. Серцевина виражена, виповнена (рис. 14).

У деяких органів спостерігається розходження клітин серцевини та корової паренхіми, між ними утворюються великі міжклітинники (рис. 9, 14).

Клітини корової паренхіми та серцевини накопичують запасну речовину - крохмаль у вигляді простих крохмальних зерен (забарвлюються у фріолетовий колір під дією розчину Люголя), а оболонки клітин судин та деяких клітин серцевини - білок (утворюється жовте забарвлення під дією розчину Люголя) (рис. 15).

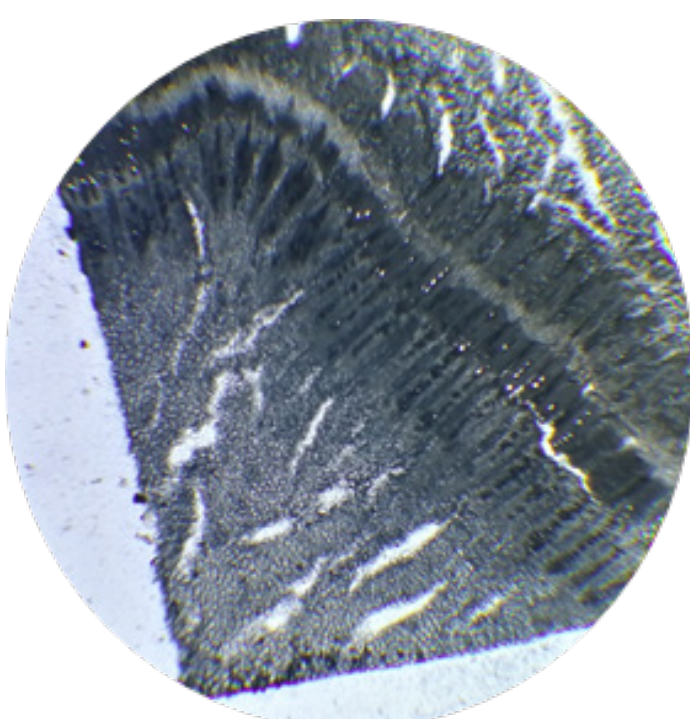

Рис. 14. Фрагмент осьового циліндра осьового органу катрану коктебельського на поперечному зрізі.

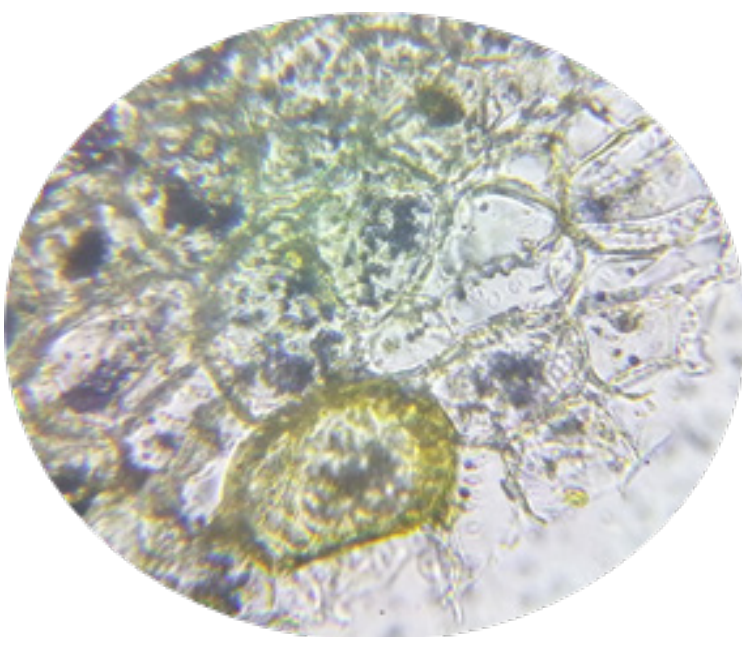

Рис. 15. Фрагмент серцевини осьового органу, клітини якої накопичують крохмальні зерна, а оболонки білок (реакція з розчином Люголя).

ISSN 2312-0967. Фармацевтичний часопис. 2021. № 3 
Висновки. Досліджено анатомічну будову підземних органів катрану коктебельського (коренів і стеблекореня) та виявлено основні мікроскопічні діагностичні ознаки, які будуть використані для розробки методів контролю якості на нову лікарську рослинну сировину.

Діагностичними ознаками кореня є:

- $\quad$ скупчення склереїд у коровій паренхімі кореня другого, третього та наступних років;

- прості крохмальні зерна з тріщинкою або з вираженими денними і нічними шарами;
- білок у клітинах ксилеми.

Діагностичними ознаками стеблекореня є:

- $\quad$ покривна тканина - багатошарова епідерма;

- $\quad$ рідке опушення простими одноклітинними волосками;

- наявність луб'яних волокон у коровій паренхімi;

- домінування у ксилемі механічної тканини.

Конфрлікт інтересів: відсутній.

Conflicts of interest: authors have no conflict of interest to declare.

\title{
ANATOMICAL STRUCTURE OF THE UNDERGROUND ORGANS OF COLEWORT KOKTEBELICA (CRAMBE KOKTEBELICA (JUNGE) N. BUSCH)
}

\author{
${ }^{1}$ S. M. Marchyshyn, ${ }^{1}$ O. Ya. Skrynchuk, ${ }^{2} D$. B. Rakhmetov, ${ }^{1}$ O. L. Demydiak \\ 1. Horbachevsky Ternopil National Medical University \\ ${ }^{2} \mathrm{M}$. Hryshko National Botanical Garden, NAS of Ukraine \\ svitlanafarm@ukr.net
}

The aim of the work. To determine the microscopic diagnostic features of the underground organs of C. koktebelica (Junge N. Busch).

Materials and Methods. Root micronutrients were prepared of freshly harvested, fixed in a mixture of ethanol-glycerinpurified water (1: 1: 1) and dried and then soaked raw materials. The anatomical structure was studied on specimen from the surface and cross-sections, which were made according to the generally accepted method. The BIOLAM LOMO light microscope (Russia) was used at a magnification of 80, 120, 160, 400, 600 and 800 times. The obtained data were recorded with OLYMPUS SH - 21 digital camera. The photos were processed using the Adobe Photoshop CS3 computer program.

Results and Discussion. Anatomical structure of the root. The root on the cross section is rounded. The periderm is represented by 2-4 layers of parenchymal cells. Cortical parenchyma formed by parenchymal thin-walled cells is welldeveloped. There are small clusters of scleroids in the roots of the second and subsequent years among the cells of the cortical parenchyma, which are absent in the roots of the first year. The structure type of the central cylinder is beamless. The cambium is well visible. The reserve substance of colewort Koktebelika root is starch, and in the membranes of the vessels of the primary and secondary xylem - protein.

Anatomical structure of root modification (stem root, caudex). Axial organ on the cross section is of a round shape. Integumentary tissue - a multilayered epidermis, the cells of which are parenchymal, thick-walled. The pubescence is sparse, represented by simple unicellular hairs. Well-developed cortical parenchyma consists of parenchymal thin-walled cells. Bast fibers are found in the crust. The central axial cylinder has a beamless structure, the cambium is well expressed. The dominant xylem tissue is libriform. The core is pronounced, filled.

Core parenchyma and core cells accumulate starch in the form of simple starch grains, the membrane of vascular cells and some core cells - protein.

Conclusions. 1. The anatomical structure of the underground organs of colewort Koktebelica (roots and stem roots) was studied and the main microscopic diagnostic features that would be used to develop quality control methods for new medicinal plant raw materials were identified.

2. Diagnostic signs of the root are:

- $\quad$ accumulation of scleroids in the cortical parenchyma of the root of the second, third and subsequent years;

- $\quad$ simple starch grains with a crack, or with pronounced day and night layers;

- $\quad$ protein in xylem cells.

3. Diagnostic signs of the stem root are:

- integumentary tissue - multilayered epidermis;

- liquid pubescence with simple unicellular hairs;

- $\quad$ the presence of bast fibers in the cortical parenchyma;

- dominance in the xylem of mechanical tissue.

Key words: colewort Koktebelica; anatomical structure; root; stem root.

ISSN 2312-0967. Pharmaceutical review. 2021. № 3 


\section{Список літератури}

1. Prina A. A taxonomic revision of Crambe, Sect. Leptocrambe (Brassicaceae). Botanical Journal of Linnean Society. 2000. Vol. 133 (4). P. 509-524.

2. Prina O. A. Taxonomic review of genus Crambe sect. Crambe (Brassicaceae). In Anales del Jardín Botánico de Madrid. 2009. Vol. 66 (1). P. 7-24.

3. Капустяні рослини: плодові і декоративні. URL: https://floristics.info/ua/statti/gorod/3534-kapustyaniroslini-plodovi-i- dekorativni.html (дата звернення: 12.04.2021). Назва з екрану.

4. Екофрлора України / А. П. Ільїнська та ін. ; відпов. ред. Я. П. Дідух. Київ : Фітосоціоцентр, 2007. 584 с.

5. Accumulation of nutrients in the raw of Crambe L. Species. O. Vergun, O. Shymanska, D. Rakhmetov et al. Agr. bio.div. Impr. Nut., Health Life Qual. 2019. P. 323-332.

6. Prakhova T. Ya. New unconventional oilseed - Abyssinian Crambe. Bulletin of Altai state agricultural university. 2013. Vol. 8, № 106. P. 8-10.

7. Алелопатичний потенціал рослин роду Crambe L. (Brassicaceae Burnett) колекції Національного ботанічного саду імені М. М. Гришка НАН України / Н. Я. Левчик, Д. Б. Рахметов, А. В. Любінська, Н. Є. Горбенко. Науковий вісник НЛтУ України. 2019. T. 29, № 5. C. 40-46.

8. Біотехнологічні підходи до збереження зникаючого виду Crambe koktebelica (Junge) N. Busch та вплив

\section{References}

1. Prina A. A taxonomic revision of Crambe, Sect. Leptocrambe (Brassicaceae). Botanical Journal of Linnean Society. 2000;133(4): 509-24.

2. Prina OA. Taxonomic review of genus Crambe sect. Crambe (Brassicaceae). In Anales del Jardín Botánico de Madrid. 2009;66(1): 7-24.

3. Cabbage plants: fruit and decorative [Electronic resource] Garden plants. Available from: https://floristics. info/ua/statti/gorod/3534-kapustyani-roslini-plodovi-idekorativni.html

4. Ilinska AP, Didukh YaP, Burda RI, Korotchenko IA. Ecoflora of Ukraine. [Екофрлора України] Kyiv: Fitosotsiotsentr; 2007. Ukrainian.

5. Vergun O, Shymanska O, Rakhmetov D. Accumulation of nutrients in the raw of Crambe L. species. Agr bio div Impr Nut Health Life Qual. 2019: 323-32.

6. Prakhova TYa. New unconventional oilseed - Abyssinian Crambe. Bulletin of Altai state agricultural university. 2013;8(106): 8-10.

7. Levchyk Nya, Rakhmetov DB, Liubinska AV, Horbenko NYe. [Allelopathic potential of plants of the genus Crambe L. (Brassicaceae Burnett) of the collection of the National Botanical Garden named after M. M. Hryshko of the National Academy of Sciences of Ukraine]. Nauk visn NLTU Ukr. 2019;29(5): 40-6. Ukrainian.

8. Pushkariova NO, Kalista MS, Kharkhota MA. [Biotechnological approaches to the conservation of the endangered species Crambe koktebelica (Junge) N. Busch and the influence of aseptic conditions of in vitro culti- асептичних умов культивування in vitro на біохімічні показники рослин / Н. О. Пушкарьова та ін. Biotechnologia acta. 2016. T. 9, № 4. С. 19-27.

9. Червона книга України. Рослинний світ / за ред. Я. П. Дідуха. Київ : Глобалконсалинг, 2009. -900 с.

10. Каліста М. С., Щербакова О. Ф., Попович А. В. Морфологічні особливості плодів Crambe koktebelica та Crambe mitridatis (Brassicaceae). Укр. ботан. журн. 2014. Т. 71, № 2. С. 188-195.

11. Ена А. А. Природная фрлора Крымского полуострова: монограсрия. Симсрерополь : Н. Ореанда, 2012. $232 \mathrm{c.}$

12. Михайлова О. А., Бирюлева Э. Г. Особенности анатомического строения вегетативных органов некоторых охраняемых видов рода Crambe L. Бюлетень ДНБС. 2013. Выпуск 10. С. 83-88.

13. Каліста М. С., Щербакова О. Ф. Біоморфогенез Crambe Koktebelica (Junge) N. Busch в умовах Карадазького природного заповідника. Інтродукція рослин. 2012. № 4. С. 16-24.

14. Основы микротехнических исследований в ботанике: справочное руководство / Р. П. Барыкина и др. - Москва : МГУ, 2000. 127 с.

15. Справочник по ботанической микротехнике: основы и методы / Р. П. Барыкина и др. Москва : МГУ, 2004. $311 \mathrm{c}$.

vation on plant biochemical parameters]. Biotechnologia acta. 2016;9 (4):19-27. Ukrainian.

9. Didukh YaP. Ed. Red Book of Ukraine. Flora. [Червона книга України. Рослинний світ] Kyiv: Hlobalkonsalynh; 2009. Ukrainian.

10. Kalista MS, Shcherbakova OF, Popovych AV. [Morphological features of fruits Crambe koktebelica and Crambe mitridatis (Brassicaceae)]. Ukr botan zhurn.2014;71(2): 188-95. Ukrainian.

11. Ena AA. Natural flora of the Crimean peninsula: monograph. [Природная фрлора Крымского полуострова : монографрия.] Simferopol: N. Oreanda; 2012. Russian.

12. Mikhaylova OA, Biryuleva YeG. Features of the anatomical structure of vegetative organs of some protected species of the genus Crambe L. Byul DNBS. 2013;10: 83-8. Russian.

13. Kalista MS, Shcherbakova OF. Biomorphogenesis of Crambe Koktebelica (Junge) N. Busch in the Karadag Nature Reserve. Introduktsiia ros. 2012;4: 16-24. Ukrainian.

14. Barykina RP, Veselova TD, Devyatov AG. Fundamentals of microtechnical research in botany: A reference guide. [Основы микротехнических исследований в ботанике: справочное руководство] Moscow: MGU; 2000. Russian.

15. Barykina RP, Veselova TD, Devyatov AG. Botanical microengineering handbook: Basics and techniques. [Справочник по ботанической микротехнике: основы и методы] Moscow: MGU; 2004. Russian.

ISSN 2312-0967. Фармацевтичний часопис. 2021. № 3 


\section{Відомості про авторів}

Марчишин С. М. - д. фрармац. наук, профресор, завідувач кафедрри фрармакогнозії 3 медичною ботанікою, Тернопільський національний медичний університет імені І. Я. Горбачевського МОЗ України, Тернопіль, Україна. E-mail: svitlanafarm@ukr.net, ORCID https://orcid.org/0000-0001-9585-1251.

Скринчук О. Я. - аспірант кафедри фрармакогнозії з медичною ботанікою, Тернопільський національний медичний університет імені І. Я. Горбачевського МОЗ України, Тернопіль, Україна. E-mail: Iliibb2121@gmail.com, ORCID https:// orcid.org/ 0000-0001-6498-3497.

Рахметов Д. Б. - Д. С.-г. наук, профресор, заступник директора з наукової роботи, завідувач відділу культурної срлори Національного ботанічного саду імені М. М. Гришка НАН України, Київ, Україна. E-mail: rjb2000.16@gmail.com, ORCID https: //orcid.org/ 0000-0001-7260-3263.

Демидяк О. Л. - канд. фрармац. наук, доцент кафредри фрармакогнозії з медичною ботанікою, Тернопільський національний медичний університет імені І. Я. Горбачевського МОЗ України, Україна. E-mail: ORCID https://orcid. org/0000-0003-0988-6058.

\section{Information about the authors}

Marchyshyn S. M. - DSc (Pharmacy), Professor, Head of the Department of Pharmacognosy and Medical Botany, I. Horbachevsky Ternopil National Medical University, Ternopil, Ukraine. E-mail: svitlanafarm@ukr.net, ORCID https://orcid. org/0000-0001-9585-1251.

Skrynchuk O. Ya. - PhD-student, Department of Pharmacognosy and Medical Botany, I. Horbachevsky Ternopil National Medical University, Ternopil, Ukraine.

E-mail: Iliibb2121@gmail.com, ORCID https://orcid.org/ 0000-0001-6498-3497.

Rakhmetov D. B. - DSc (Agriculture), Professor, Deputy Director for Research, Head of the Department of Cultural Flora, M. M. Hryshko National Botanical Garden of the National Academy of Sciences of Ukraine, Kyiv, Ukraine. E-mail: rjb2000.16@gmail.com, ORCID https: //orcid.org/ 0000-0001-7260-326.

Demydiak O. L. - PhD (Pharmacy), Associate Professor of the Department of Pharmacognosy and Medical Botany, I. Horbachevsky Ternopil National Medical University, Ternopil, Ukraine. E-mail: ORCID https://orcid.org/0000-0003-09886058. 